2013-5

\title{
Rationalizing Creativity-Rationalizing Public Service: Is Scheduling Management Fit for the Digital Era?
}

Ann-Marie Murray

Technological University Dublin, annmarie.murray@tudublin.ie

Follow this and additional works at: https://arrow.tudublin.ie/aaschmedart

Part of the Communication Commons, and the Film and Media Studies Commons

\section{Recommended Citation}

Murray, Ann-Marie, (2013) Rationalizing Creativity-Rationalizing Public Service: Is Scheduling Management Fit for the Digital Era?, The International Journal on Media Management , 15:119-136, 2013 ISSN: 1424-1277 DOI:10.1080/14241277.2013.782500

This Article is brought to you for free and open access by the School of Media at ARROW@TU Dublin. It has been accepted for inclusion in Articles by an authorized administrator of ARROW@TU Dublin. For more information, please contact arrow.admin@tudublin.ie, aisling.coyne@tudublin.ie,gerard.connolly@tudublin.ie.

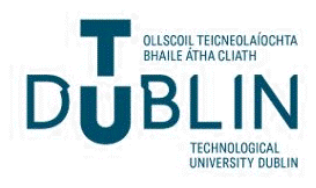


This article was downloaded by: [Dublin Institute of Technology]

On: 12 November 2013, At: 04:06

Publisher: Routledge

Informa Ltd Registered in England and Wales Registered Number: 1072954 Registered office: Mortimer House, 37-41 Mortimer Street, London W1T 3J H, UK

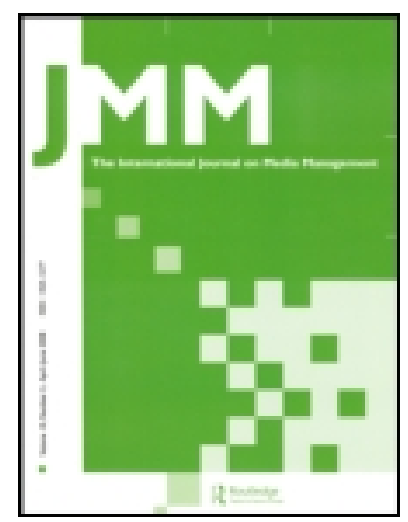

\title{
International J ournal on Media Management
}

Publication details, including instructions for authors and subscription information:

http:// www.tandfonline.com/loi/ hijm20

\section{Rationalizing Creativity-Rationalizing Public Service: Is Scheduling Management Fit for the Digital Era?}

\author{
Ann-Marie Murray ${ }^{a}$ \\ ${ }^{a}$ Centre for Media Studies, National University of Ireland, \\ Maynooth, Maynooth, Co. Kildaire, Ireland \\ Published online: 28 May 2013.
}

To cite this article: Ann-Marie Murray (2013) Rationalizing Creativity-Rationalizing Public Service: Is Scheduling Management Fit for the Digital Era?, International J ournal on Media Management, 15:2, 119-136, DOI: $10.1080 / 14241277.2013 .782500$

To link to this article: http:// dx.doi.org/ 10.1080/ 14241277.2013.782500

\section{PLEASE SCROLL DOWN FOR ARTICLE}

Taylor \& Francis makes every effort to ensure the accuracy of all the information (the "Content") contained in the publications on our platform. However, Taylor \& Francis, our agents, and our licensors make no representations or warranties whatsoever as to the accuracy, completeness, or suitability for any purpose of the Content. Any opinions and views expressed in this publication are the opinions and views of the authors, and are not the views of or endorsed by Taylor \& Francis. The accuracy of the Content should not be relied upon and should be independently verified with primary sources of information. Taylor and Francis shall not be liable for any losses, actions, claims, proceedings, demands, costs, expenses, damages, and other liabilities whatsoever or howsoever caused arising directly or indirectly in connection with, in relation to or arising out of the use of the Content.

This article may be used for research, teaching, and private study purposes. Any substantial or systematic reproduction, redistribution, reselling, loan, sub-licensing, systematic supply, or distribution in any form to anyone is expressly forbidden. Terms \& Conditions of access and use can be found at http://www.tandfonline.com/page/termsand-conditions 


\title{
Rationalizing Creativity-Rationalizing Public Service: Is Scheduling Management Fit for the Digital Era?
}

\author{
ANN-MARIE MURRAY \\ Centre for Media Studies, National University of Ireland, Maynooth, \\ Maynooth, Co. Kildaire, Ireland
}

In public broadcast organizations across Europe, scheduling has been transformed from a marginal, administrative activity to a bighly strategic management tool (Hellman, 1999; Hujanen, 2002; Meier, 2003; Ytreberg, 2000). Ellis (2000) described it as "the locus of power in television," organizing production and managing budgets (p. 26). The role of scheduling in public broadcast organizations today reflects the demands of increasing competition and political pressure for efficiency and accountability. However, new challenges have emerged in the transition from public service broadcasting to public service media (PSM). PSM providers must redefine their mission for the digital era and find new ways to engage audiences and enrich their societies. They also have to navigate a new competitive and regulatory environment, as they begin to compete in a cross-platform market with a range of media services. Adapting to this new arrangement will require creativity and innovation from content creators. However, as this article shows, scheduling management limits producer autonomy and inhibits creativity. Based on in-depth, qualitative interviews with key personnel from Radio Teilifís Eireann (RTÉ), Ireland's public broadcast organization, this article examines how rationalization of scheduling practices has enabled management to maximize competitiveness and cost efficiency. However, it argues that the schedule-led system curbs creative freedom and ultimately threatens to undermine the public service that RTE provides. It is timely then, at this critical juncture, to examine whether scheduling management has anything to offer PSM organizations in the

Address correspondence to Ann-Marie Murray, Centre for Media Studies, Arts Building, National University of Ireland, Maynooth, Co. Kildaire, Ireland. E-mail: annmarie.murray@dit.ie 
digital era or if it should be abandoned in favor of a third model of management.

Scheduling has always been, to some degree, a competitive activity, since it involves competing for viewers' time (Abercrombie, 1996, p. 132). For a long time, however, especially where public service monopolies operated, this was a relatively easy task. However, since the mid-1990s, in public broadcast organizations across Europe, particularly Northern Europe, scheduling has been transformed from a relatively marginal activity to a highly strategic management tool (Hellman, 1999; Hujanen, 2002; Meier, 2003; Ytreberg, 2000). Today, it refers not just to the task of placing programs in time-slots, but encompasses the whole process of evaluation, strategic planning, and commissioning and program selection. The role of scheduling in public broadcast organizations today reflects the demands of increasing competition and political pressure for efficiency and accountability. These competitive, economic, and political pressures still exist, as audiences continue to fragment and public broadcasters face increasing scrutiny regarding their role and the scope of their activities.

However, new challenges have emerged in the transition from public service broadcasting (PSB) to public service media (PSM). PSM providers must redefine their mission for the digital era and find new ways to engage audiences and enrich their societies. They also have to navigate a new competitive and regulatory environment, as they begin to compete in a cross-platform market with a range of media services. It is timely then, at this critical juncture, to examine whether scheduling management has anything to offer PSM providers in the digital era.

This article presents research into the transformation of scheduling practices in Radio Teilifís Eireann (RTÉ), Ireland's public broadcast organization. Drawing on in-depth, semi-structured interviews with senior management personnel and producers from RTÉ, this article examines how rationalization of scheduling has allowed management to take greater strategic, editorial, and budgetary control over program output. ${ }^{1}$ It presents the accounts of seven individuals involved in scheduling, programming, and production in RTÉ. Four of the respondents were working in senior management positions in RTÉ Television at the time the interviews were carried out. Their responsibilities included sales, programs (in-house production and commissioning), acquisitions, and schedule planning. Another had worked in a senior management position in scheduling in the mid-1990s, when competition was intensifying. Two producers were also included, to offer an insight into how scheduling practices affect the production process. One had worked as a series producer of current affairs and factual programming during the 1980s and 1990s, before leaving the organization in 2002. The second worked in the independent sector between 2000 and 2009. Interviews were carried out over 
a two-month period in 2006, following radical organizational change, which positioned scheduling as the central management tool in RTÉ Television.

Søndergaard (2002) pointed out that, although there is literature available on the changes in scheduling, there are still very few studies on the "institutional and organisational transformations behind these changes" (p. 5). Following the work of Hellman (1999), Hujanen (2002), Meier (2003) and Ytreberg (2000), this research goes some way toward filling that gap, focusing on the organizational shift toward a schedule-led, ratings-driven approach in RTÉ Television and the consequences of that shift for PSB. This article shows that by adopting a rationalized approach to scheduling, RTÉ management have been able to maximize audience share while maintaining financial viability and fulfilling their legal requirements. Yet, although this is a necessary response to environmental pressures, RTÉ management have applied rules and a scientific rationality to an activity that was previously outside of their remit. They now control production to such an extent that producer autonomy is undermined and creativity, a fundamental element of the public service remit, is inhibited (Blumler \& Nossiter, 1991, p. 422; Croteau \& Hoynes, 2006, p. 37). This signals a fundamental transformation in the nature of the public service delivered by RTÉ. Moreover, it has serious implications for public broadcasters' abilities to innovate and adapt for the digital era. Therefore, this article considers if a new management model is required for the transition from PSB to PSM, as Nissen (2011) suggested.

\section{RTÉ: A QUASI-COMMERCIAL PSB}

RTÉ is Ireland's PSB organization, which provides, inter alia, two national television channels on a free to air basis throughout the Republic of Ireland. Although the Irish broadcast sector was only officially deregulated in 1988, RTÉ has always operated in a competitive environment. From the beginning, channels from the United Kingdom, Ireland's nearest, same-language neighbor, were available, initially along the East coast and border counties over the air, due to signal spill-over, and later across the country via cable, Multipoint Microwave Distribution System, and satellite (Hazelkorn, 1995, p. 101; Kelly \& Truetzschler, 1997, p. 119). Cable and satellite channels were widely available by the mid-1990s, which meant that even in the monopoly era, RTÉ was "thoroughly inundated by English language satellite TV" (Humphreys, 1996, p. 190). Domestic competition finally arrived in 1998, with the launch of TV3, posing a further threat to RTÉ's audience share and advertising revenue.

RTÉ is funded through a combination of licence fee receipts and commercial revenue; from television, radio, and online advertising; and publishing. Commercial revenue makes up approximately 50\% of RTÉ's income, leading Shaw, Picard, and Abbink Spaink (2010) to describe it as "a highly 
commercial public service broadcaster" (p. 8). Moreover, they noted that this balance

defines public policy which sees RTÉ at the centre of Ireland's cultural life. ... Effectively commercial funding, and commercial activities, in RTÉ's analysis, enables it to be a stronger PSB, offering more services than a small nation state can support. (pp. 112-113)

In other words, Irish public policy demands that RTÉ fulfil its public service obligations while operating as a quasi-commercial broadcaster. Management at RTÉ therefore have to balance these competing demands of commercial viability and public service. In response, the organization has adopted a rationalized approach to scheduling and programming practices.

\section{THE RISE OF SCHEDULING}

Scheduling used to be thought of as little more than a matter of placing programs in time slots. In the BBC, for example, scheduling was for many years mainly an administrative function, to combine the programs that producers provided (Ellis, 2000, p. 26). This was an offer-led system (Søndergaard, 2002, p. 10), and it reflected the organization's culture, where autonomy was regarded as a fundamental aspect of the producer's professional identity (Murdock, 1993, p. 125). This is not to say that scheduling was inconsequential or uncompetitive; as Ytreberg (2002) noted, "the wish to maximize the time-continuous viewing of several programs lay at the base of scheduling as a craft" (p. 286). This was particularly the case for public broadcasters, like RTÉ, which were operating in a competitive environment.

However, in the mid-1990s, scheduling took on strategic importance, as multi-channel competition intensified across Europe and public broadcasters had to work much harder to attract and hold onto audiences (Søndergaard, 2002, p. 7; Ytreberg, 2000, p. 26). This was vital for public and political support in an environment where performance was increasingly measured by ratings; it was also essential for those broadcasters that depended on advertising revenue. As the former head of scheduling remembers, there was now a growing realization that, in the multi-channel era, good programs by themselves were not enough. Rather, the design of the schedule would be critical to maintaining overall audience share for the channel (or set of channels) in a busy, multichannel environment:

Of course, the programs are the fundamental building blocks, but what they build is the schedule. The programs can bring people in to a schedule, and if the schedule is correctly designed, those people can be held onto or increased in number. And then, our commercial colleagues can 
sell that value and there'll be more money for program making, and the quality of the whole thing can rise. That was the basic thesis. (Int. C, personal interview $)^{2}$

To design a more competitive program schedule, the needs of the schedule would have to drive production from the beginning; therefore, senior management needed greater control over programming. At this point, Søndergaard (2002) noted that public broadcasters began to devote more staff and resources to scheduling (p. 7).

The rise of scheduling management was not simply a response to competition, however; it was also driven by growing economic and political pressures, which public broadcasters faced in a deregulated European broadcast market. As Hujanen (2000) argued, "the standard accusation was that public service broadcasters were economically inefficient and were wasting public resources" (p. 75). In Ireland, RTÉ was operating at a loss by the late 1990s and was under intense public and political scrutiny in relation to its spending. The broadcaster recognized it would have to address its costs and improve accountability to justify any increases in public funding. It was, as Hellman (1999) put it, a "dual problem of economy and legitimacy" (p. 27).

Facing rising costs and under pressure to justify their existence in an increasingly hostile ideological climate, RTÉ, like public broadcasters across Europe, had to prioritize cost efficiency and accountability (Ytreberg, 2002, p. 292). Senior management needed to take control of programming to track spending and ensure that all programs fulfilled strategic policy objectives. Over 2002 and 2003, following a review by external consultants, RTÉ engaged in major organizational restructuring, designed to improve accountability, increase revenue, and strengthen output (Logical and KPMG, 2002, pp. 45-46). The recommendations included reorganizing RTÉ into six distinct divisions known as Integrated Business Divisions, to bring about greater efficiencies and introduce a commercial focus (Logical and KPMG, 2002, p. 45). As part of this, RTÉ Television was established as a separate business unit and, at the same time, the Division implemented two key changes to position scheduling as the central management tool.

The first was the establishment of the Program Strategy Group (PSG); the second was the introduction of the Schedule-Based Budgeting and Planning (SBBP) system. The PSG is composed of senior management personnel from all areas of the television division. It is responsible for the overall strategic direction of the schedule and decides on the content of each slot; one member of the PSG described it as "the most senior editorial group in the Division" (Int. D., personal interview). The SBBP system is a budgeting system that marries production and commissioning activities to the financial management of the organization.

These measures strengthened the scheduling and program planning function by giving management greater control over programming and 
allowing strategic goals to drive output. It allowed management to track and control spending. Implementing scheduling as a management tool, therefore, addressed the need for strategic and editorial control, cost efficiency, and accountability. Thus, as Søndergaard (2002) argued, "the schedule constitutes not only a strategic area as regards competition, but it also functions as [an] important means of organising programme production and resource management" (p. 3). This is imperative at a time "when the money available for public service broadcasting is limited" (p. 6).

This effort to improve control, efficiency, and accountability may be understood in terms of Weber's (1978) theory of rationalization, as an attempt to apply a formal rationality to scheduling and programming practices. ${ }^{3}$ In a bureaucracy, any mechanism that enhances control, efficiency, and calculability makes the organization more rational. In RTÉ, scheduling management achieves hierarchical control because the PSG drives programming and commissioning decisions. It also provides cost control because the SBBP system ties spending directly to the schedule. Each slot is valued in terms of audience share and advertising revenue, which enhances calculability. Under this system, the budget for each program is linked to the expected revenue for its time slot; this improves cost efficiency and accountability while encouraging a greater commercial focus.

As a result of these structural changes, everything now revolves around the schedule. The schedule-led system "integrates the overall management of the channels with planning and commissioning functions" (Hujanen, 2002, p. 73). Born (2004) argued that scheduling has become

the point of integration for television's expanding components: strategy, marketing, commissioning, production, accounting; and as all of these bear on the broad editorial judgements that in turn inform practical decisions on finer details of genre and format-on what will be shown. (p. 294)

Thus, management can maintain strategic, creative, and budgetary control over program output. This has resulted in a qualitatively new approach to program making - one that ultimately threatens the scope for creativity and innovation in public broadcasting.

\section{BUDGET CONTROL}

Rather than planning on a season-by-season basis, the PSG now prepares the schedules up to one year in advance. This allows for strategic planning while also acting "as a measure of economic control" (Hujanen, 2002, p. 102). Under the SBBP system, the budget and the schedule work "in tandem" (Int. B, personal interview), and all production, acquisitions, and 
commissions are "based around the available budget" (Int. F, personal interview). This is equivalent to the system that operated in Yle (the Finnish public broadcaster) during the 1990s, where the scheduling cycles "move in close connection with the budgetary process" (p. 81). It ties all spending to the schedule, ensuring that only programs that fit the needs of the schedule are produced or acquired: "[N]o program is commissioned these days without a schedule slot in mind" (Int. B, personal interview). This contributes to cost efficiency by preventing unecessary expenditure on the development of programs that have "little chance of getting on screen" (Born, 2004, p. 256). Yet, it goes even further by matching the budget for a program to its anticipated revenue.

Under this system, a program's budget is based on its intended slot and how much investment is required to achieve the expected share for that slot. As one interviewee put it, "[S]o, the money tends to chase the slot. ... We know the value of the slot and how much we need to spend to get good numbers" (Int. D, personal interview). The budget-slot logic dictates that no more should be spent on a program than is necessary to win the anticipated share for the slot. This approach is highly cost efficient; however, it has resulted in what Born (2004) described as "lowest common denominator" logic ruling the schedule: "[I]f it was possible to get an equally good audience for a slot with a cheaper show, then that's what should be done" (p. 307).

The budget-slot logic reflects an attempt to impose a commercial rationality, whereby program budgets are calculated strictly on the basis of costs versus revenue. Commercial rationality would dictate that less profitable programs be removed from the schedule altogether. However, as a public service broadcaster, RTÉ is obliged to serve a plurality of audiences and provide a range of programs that the commercial sector may not. Nonetheless, RTÉ still attempts to minimize damage to audience share by scheduling such programs (e.g., religious programs) in less competitive slots. Furthermore, management at RTÉ will endeavor to balance the books through complementary scheduling - that is, if they invest heavily in a program that is not likely to achieve a very high share, they are careful to schedule a more popular show on the other channel:

Arts Lives is expensive, and a full Arts Lives commission could be 70 or 80 grand, but we know that's not about getting numbers; it's about the quality of the idea and the production. At the same time, we've Desperate Housewives on RTÉ2 - that's no accident! . . . So, we're maximizing the opportunity there. (Int. D, personal interview)

Thus, by applying a strategic approach to schedule design, RTÉ can fulfil its public service duties while maximizing audience share and commercial revenue. 


\section{MANAGING PRODUCTION}

In addition to cost control, scheduling management also offers strategic and creative control. In RTÉ, the Television Division is now organized in such a way that production, acquisition, and commissioning functions serve the needs of the schedule - that is, the schedule comes first, programs second; or, as Ellis (2000) put it, the schedule "orders programmes" (p. 33). This ensures a flow-through from strategic planning to program output. The scheduleled approach has become essential in an era of accountability, where public broadcasters have to meet specific programming commitments (see Coppens \& Saeys, 2006, p. 266). Through advance planning and by taking a holistic approach to schedule design, rather than waiting to see what comes from producers, management can ensure that these targets are met.

This concern to maintain strategic and creative control over program output has also arisen out of a need to predict audience share. In recent years, audience share has become critical for public broadcasters, both for political legitimacy and financial survival. As the former independent producer reasoned, "[T]hey would argue ... if you want a unique Irish broadcaster, the only way we're going to survive is we've got to have bums on seats" (Int. G, personal interview). Moreover, advertisers will pay more if they can accurately predict the share for a program (Napoli, 2001, p. 54). Consequently, RTÉ is unwilling to risk a drop in ratings, and once there is evidence that a particular format works in a slot, there is a tendency to repeat tried and tested formulas. One interviewee from the PSG described trying to emulate the success of a Sunday evening family entertainment show:

[Y]ou decide, okay, once You're a Star finishes, we want to have another program that will attract the same kind of audience, that will have a competitive element, that will be fun, that will be glitzy, and that will fill a whole hour between half six and half seven. (Int. B, personal interview)

The program that was eventually commissioned to replace You're a Star met these specifications; Celebrity Jigs and Reels was a dance competition with well-known contestants aimed at a family audience. It was commissioned because the format had a proven track record in that slot.

Once the PSG has decided on the needs of the schedule and allocated the budget for each slot, these are communicated to producers via commissioning editors:

... [S]o you sit down with the commissioning editors and you go "Right, we want you to look for this" ... and we try to make it specific. ... We say to them ... "We'd like a lifestyle program on Monday night that is male skewing," etc., etc. So, we give them as much information as possible .... (Int. E, personal interview) 
Before, producers were given basic direction from department heads in relation to the program topic, but had relative freedom in respect of the content of the show:

Well, it was prescriptive insofar as you were told to go off and do, you a health program or an arts program or whatever. You had a considerable degree of freedom within that ... it was up to you what you then did. (Int. A, personal interview)

This indicates that, although producers had very little opportunity to contribute program ideas for the schedule-the same respondent spoke of a "hand-me-down schedule" - they still enjoyed a significant amount of autonomy (Int. A, personal interview; the system in RTÉ was, therefore, closer to Søndergaard's, 2002, organizational-led model than the offer-led system that operated in the BBC). Under the schedule-led system, however, producers are much more restricted. The PSG provides detailed prescription and, although producers are still expected to come up with ideas, they must fit within strict parameters set by management. The former independent producer explained: "[T]hey are quite specific now in telling you the time slot and the audience they have and what's filled it before and what they're looking for" (Int. G, personal interview). Production companies must incorporate these elements into their pitch if they are to be successful in the commissioning round. This kind of direction is helpful for producers seeking a commission-"You can't operate blind" - and they adapt to this formulaic approach (Int. G, personal interview):

... [T]hey'll say, "What's really worked for us over the past five years," and they'll name four or five shows that have really worked for them. So, you're obviously gonna use your head and say, right, those are the four or five shows that worked prior to this in this slot so they're looking for more of the same (Int. G, personal interview)

Because future programming decisions are based on retrospective data, the effect, as Born (2004) argued, is "to encourage a shift in the mindset of the entire production community towards thinking in ever more standardised terms" (p. 311).

The schedule-led, ratings-driven approach has now also become the modus operandi for producers. A member of the PSG described how producers can access audience measurement data and incorporate this into their program development:

... [S]o you can actually go and say, "Who's available in that slot, who watched it last year, what are other people watching on other channels?," you know, so you just really examine the slot from every single aspect, 
and at the end you go, "Well, my main core available demographic at that time is: this," and then you can tailor your material to it . . . which is to me common sense, you know .... (Int. E, personal interview)

This is a "qualitatively different approach" to program making (Int. C, personal interview). As Hujanen (2004) argued, whereas before the imagined audience for a program might be based on the producer's instinct or anecdotal evidence, today it is "based on a careful analysis of the audience-research data in relation to the particular slots" (p. 138). In this way, management maintain control over producers, not through direct hierarchical control, but via the schedule and the ratings-driven production method.

Rationalization of scheduling practices has been crucial to RTÉ's financial survival. It also addresses the broadcaster's need to maintain a strong audience share, which is vital to secure political support. However, although the schedule-led system may be more rational from a commercial perspective, because it is easier to predict the ratings for the new program, it limits the opportunities to introduce new ideas. As the Sunday night entertainment slot illustrated, once there is evidence that a particular format works, there is a tendency toward repeating tried and tested formulas. Furthermore, because the ratings-driven approach allows management to exert control over the kinds of programs that are made, it limits producer autonomy and inhibits creativity.

Yet, there was a strong sense from respondents that their priority is not to protect the autonomy of the producer, but to ensure that programs meet the needs of the schedule. One suggested that the old auteur approach was not responsive to the needs of the audience:

You see, back then I think ... program making was often thought of as a kind of electronic authorship. You know, "Making a programme is like writing a book and ... I'll write the book I want to write." Whereas now, I think, it's much more about saying "What does the audience want?" (Int. C, personal interview)

Another respondent, from the Programs Department, argued:

I think the day is gone when you can go, "I've a great idea; I'll make a program about fruit! 'Cos I think I really should." You can't do that anymore; you have to know where it's for and why you're making it. There needs to be a rationale. (Int. E, personal interview)

The facetious comment about making programs on a whim exposes an attitude among management that the old system indulged the elitist, artistic motivations of producers. In contrast, management regarded the new system as a more appropriate and rational, or "common sense," way to serve 
the audience in the current environment (Int. E, personal interview). When challenged on whether the schedule-led system negatively affects production and the creative process, one respondent emphatically replied, "No, I think it's very positive. Look, people, the public pay for this" (Int. C, personal interview). This indicates that management have internalized the principles of accountability and value for money as core elements of public service.

It is evident that the schedule-led system closes down the possibilities for risk-taking and inhibits creativity and innovation. However, the level of strategic, editorial, and budgetary control that the system offers is indispensable to managers as they seek to balance the demands of increasing competition and political pressure for efficiency and accountability. The adoption of scheduling as a management tool is, therefore, a practical and reasonable response in the current political-economic context. However, new issues are now emerging, in the transition from PSB to PSM, which may force RTÉ to adapt this system or abandon it altogether in favor of a "third model" of management (Nissen, 2011).

\section{IS IT TIME FOR A NEW MANAGEMENT SYSTEM?}

Nissen (2011) argued that we have already seen two phases in public service management: During the first, in the monopoly era, program makers held the power, and administrators served their needs; in the second, after competition arrived, the balance shifted as management took back control (p. 8; see also Born, 2004, p. 213; Burns, 1977, p. 25). Scheduling management arose in this second phase; it offered the kind of control that management demanded in their pursuit of cost efficiency and competitiveness. However, Nissen predicted that a third-generation model of management is needed for the digital era-one that is more decentralized and can put content creators closer in touch with their audiences (p. 15). In this new model, top management will have to adopt a more hands-off approach in respect of content production, although Nissen maintained that "the central control of total output and the overall use of resources will have to continue" (p. 16). So, is scheduling management fit for the digital era? Should it be abandoned altogether, or can it be adapted for a third model of public service management?

It should be noted, incidentally, that the primary threat to scheduling management in the digital era is not the so-called death of the schedule. Some might argue that because the days of the schedule are numbered, scheduling can no longer function as a management tool. However, today, scheduling in public broadcast organizations has expanded to include a range of activities, including audience research and commissioning. This more closely corresponds with Eastman and Ferguson's (1997) definition of programming - a practice that developed in commercial broadcast organizations in the United States and that encompasses the whole process of 
scheduling, program selection, and evaluation (p. 6). This expansion of activities signals the permeation of commercial logics and practices, and also reflects the desire among public service managers for greater strategic control. When scheduling is redefined to take account of this shift, it is clear that it will continue to be a controlling force in the future (Ytreberg, 2000, p. 26). Whether the programs are consumed as part of a linear schedule or on-demand, via the television set or online, there will still need to be some editorial center that controls output. This is necessary both to ensure that content fulfils the organization's legal obligations and to manage resources.

Of more concern is the effect that the schedule-led system has on creativity. Creativity is the lifeblood of any cultural endeavor, and it is critical from a public interest perspective because it is essential to allow new ideas and formats to emerge which might better reflect the concerns and interests of the public. Croteau and Hoynes (2006) argued that "innovation and risk taking-including promoting fresh perspectives, developing new formats, and welcoming controversy-are part of what it means to serve the public interest" (p. 37). As such, sustaining and encouraging creativity should always be a priority for public broadcast organizations (see Blumler \& Nossiter, 1991, p. 422). However, it will be of vital importance as public broadcasters transition to become PSM operators.

With an ever increasing range of linear and on-demand broadcast services, as well as Internet services such as YouTube, social networking, and gaming, audience fragmentation is set to continue apace. Public service providers must compete with these services if they are to remain relevant in the all-media landscape. Furthermore, most institutions across Europe now offer a range of online services in addition to broadcast content, although some commission specific projects on a multiplatform basis (see Bennett, 2008; Gunn, 2008; Moe, 2008).

RTÉ already offers a range of Internet, on-demand, and mobile phone services. Some digital channels, consisting of content repacked from the existing channels and high definition services, have been launched since the roll-out of the digital terrestrial television platform. At the level of programming, commissioning editors in certain program areas, such as entertainment, children, and factual, seek to develop projects on a multiplatform basis. However, these projects are limited, and RTÉ has not yet made the transition to a full multiplatform approach, partly due to financial restrictions. Crucially, there has been no change to the schedule-led system. The PSG and the SBBP systems still function in the same way, maintaining strategic and editorial control and assigning budgets to slots.

In the future, however, once resources permit, and provided the European regulatory framework allows for such an expansion of the public service remit (see Debrett, 2009), this "360" approach is likely to become the norm. Digital extras will be more closely integrated with mass media content, enabling enhanced audience participation. Gunn (2008) noted that 
the focus on participation in a multi-platform context "can be seen as an adaptation of classic PSB ideals of public access and audience participation" (p. 117). Thus, in redefining public service for the all-media environment, content providers must develop new formats that can engage audiences across platforms. Nissen (2011) noted:

[P]rogram makers, who for generations have been trained in making good, linear story-lines being [sic.] it in a documentary, a piece of drama or an entertaining music contest, will have to develop new non-linear narrative methods inviting the users to interrupt with questions, to provide suggestions and even to come up with their own stories. (p. 14)

Adapting to this new arrangement will require creativity and innovation from content creators.

\section{RATIONALIZING CREATIVITY: RATIONALIZING PUBLIC SERVICE}

Organizing creativity is, to some, an oxymoron; yet, that is the challenge for cultural institutions and businesses. There is an inherent tension between the "arationality of the creative process" and the formal rationality of bureaucratic organizations (Hesmondhalgh \& Baker, 2006, p. 6; see also Donaldson, 1996, p. 54). Moreover, autonomy and freedom from commercial pressures are considered vital in safeguarding artistic motivation and encouraging creativity (Eikhof \& Haunschild, 2007, p. 534; see also Alvesson \& Thompson, 2005, p. 493; Küng, 2008, pp. 151-153). Indeed, autonomy was traditionally regarded as a fundamental aspect of the producer's professional identity (Murdock, 1993, p. 125; see also Hesmondhalgh, 2007, p. 198).

Nevertheless, some claim that control from management need not inhibit creativity and argue that, in fact, creative work can and should happen within limits (Amabile, 1998, p. 81; see also Küng, 2008, p. 154). Amabile argued that management can set the overall strategic goals and dictate the budget and timeframe while still allowing cultural workers the space and autonomy to do creative work (p. 81). In other words, management define what should be done and leave creative workers free to decide how to do it. Gallagher (1982) referred to this as tactical autonomy versus strategic control (p. 167), whereas Amabile argued that creative workers should be given autonomy in respect of "the means ... but not necessarily the ends" (p. 81). On the face of it, this is what scheduling management achieves. The PSG decides on the requirements and the budget for each slot; producers then pitch their ideas to commissioning editors. In this way, management maintain control over costs and strategic outcomes while leaving producers free to make programs. This, apparently, is exactly the kind of model Nissen (2011, p. 16) called for. 
Scheduling management may also fit with the decentralized structure that Nissen (2011) argued would be necessary in the digital era. The scheduling management system represents a revised version of bureaucracy wherein the schedule acts as a form of control over resources and as a means of integrating strategy and action. Everything now revolves around the schedule. It is the nexus between all activities within the division, linking revenue generating activities, resource management, and production. To use Sennett's (2006) analogy, it is the "institution's central processing unit" that sets the tasks and judges results (p. 51). In particular, the ratings-driven approach to production acts as a form of indirect control by ensuring that producers tailor their programs to the needs of the schedule, as defined by ratings data.

However, although this system may appear to offer management a mechanism for setting corporate strategy and monitoring resources while leaving the rest to the creative workers, in fact, it goes much further than this. The PSG has editorial responsibility for the schedule and, together with commissioning editors, makes key creative decisions for programs, specifying items such as the subject matter, style, tone, and target audience. Scheduling management, therefore, represents the formal incorporation of creative work into the domain of management (for a discussion of incorporation as a management strategy in creative organizations, see Davis \& Scase, 2000, p. 73).

When creativity, a fundamentally a-rational process, is integrated into management structures, it becomes subject to control, calculability, and predictability and is transformed from an instinctive, producer-led activity into a scientific, ratings-driven practice. Weber (1978) warned that formal rationality may be inimical to certain purposes, pointing to the consequences of "the specifically modern calculating attitude" (p. 86). Furthermore, creative freedom is limited when management have to concern themselves with financial, competitive, and regulatory issues. Management must take responsibility for the organization's survival, and this will mean, for example, they are less likely to take a risk with a slot or to spend money on a program for "art's sake." Tracey (1998) argued that the rules of broadcasting should liberate, rather than restrict, the program-maker, but the schedule-led system curbs creative freedom (p. 31).

Yet, as long as RTÉ depends on commercial revenue, managers will have to obey audience ratings and will be unwilling to take risks; and, while regulators demand measurable performance indicators, managers will have to exert editorial control to ensure that programming commitments are met. Therefore, PSM organizations, particularly those funded by commercial revenue, will need scheduling management for some time to come. Now, given the kind of indirect, center-out form of control that scheduling management offers, it could indeed be a useful system for PSM's future decentralized, organizational structures. However, unless the system is modified to minimize 
commercial pressures and grant more freedom to content creators, it cannot deliver the creativity that PSMs will need in the digital era.

\section{ACKNOWLEDGMENT}

The research was supported by the School of Media, Dublin Institute of Technology, Ireland.

\section{NOTES}

1. In addition to the qualitative interview data, the study is based on an analysis of changes in program output and scheduling practices over a 15-year period, from 1990 to 2005, along with an examination of primary source documents, such as annual reports and corporate review documents (see Murray, 2011).

2. Interviewee (Int.) A is a television producer, who worked in Radio Teilifís Eireann (RTÉ) during the 1980s and 1990s as a series producer of current affairs and factual programming. Int. B works in a senior management position in RTÉ Television with responsibility for broadcast (including schedule planning, promotions, press, and publicity) and acquisitions. Int. C works at a senior management level in another major division within RTÉ. This individual worked in scheduling in the mid-1990s. Int. D has the responsibility for schedule planning in RTÉ Television and is a member of the PSG. Int. E works in a senior management position in the Programs Department of RTÉ Television. Int. F works in a senior management position in the Sales Division.

3. It has been argued that Weber's (1978) model of bureaucracy is not relevant in the current socioeconomic context (see Alvesson \& Thompson, 2005, p. 486; Courpasson \& Reed, 2004, p. 7; Höpfl, 2006, p. 8; McSweeney, 2006). However, despite significant changes in organizational structures and practices, particularly since the 1970s, Weber's bureaucracy model is still a relevant and valuable analytical tool. For example, although the hierarchical structure may have been adapted, control is achieved, although in different ways (Bagguley, 1991; Briand \& Bellemare, 2006; Courpasson, 2000; Heckscher, 1994; Kärreman \& Alvesson, 2004; Procter, 2005; Walton, 2005, p. 588). Therefore, although organizations today may be structured differently than in Weber's time, they do not operate according to a radically new "organizing rationality or logic" (Courpasson \& Reed, 2004, p. 7). For further discussion of Weber's theory of rationalization as a framework for understanding scheduling management, see Murray (2011).

\section{REFERENCES}

Abercrombie, N. (1996). Television and society. Cambridge, England: Polity Press.

Alvesson, M., \& Thompson P. (2005). Post-bureaucracy? In S. Ackroyd, R. Batt, P. Thompson, \& P. Tolbert (Eds.), The Oxford handbook of work and organization (pp. 485-507). Oxford, England: Oxford University Press.

Amabile, T. (1998, September-October). How to kill creativity. Harvard Business Review, 78-87.

Bagguley, P. (1991). Post-Fordism and enterprise culture: Flexibility, autonomy and changes in economic organization. In R. Keat \& N. Abercrombie (Eds.), Enterprise culture (pp. 151-170). London: Routledge.

Bennett, J. (2008). Interfacing the nation: Remediating public service broadcasting in the digital age. Convergence, 14, 277-294. 
Blumler, J., \& Nossiter, T. (1991). Broadcasting finance in transition: A comparative handbook. New York: Oxford University Press.

Born, G. (2004). Uncertain vision: Birt, Dyke and the reinvention of the BBC. London: Secker and Warburg.

Briand, L., \& Bellemare, G. (2006). A structurationist analysis of post-bureaucracy in modernity and late modernity. Journal of Organizational Change Management, 19, 65-79.

Burns, T. (1977). The BBC: Public institution and private world. London: Macmillan.

Coppens, T., \& Saeys, F. (2006). Enforcing performance: New approaches to govern public service broadcasting. Media Culture and Society, 28, 261-284.

Courpasson, D. (2000). Managerial strategies of domination. Power in soft bureaucracies. Organization Studies, 21, 141-161.

Courpasson, D., \& Reed, M. (2004). Introduction: Bureaucracy in the age of enterprise. Organization, 11, 5-12.

Croteau, D., \& Hoynes, W. (2006). The business of media: Corporate media and the public interest (2nd ed.). Thousand Oaks, CA: Pine Forge.

Davis, H., \& Scase, R. (2000). Managing creativity. Buckingham, England: Open University Press.

Debrett, M. (2009). Riding the wave: Public service television in the multi-platform era. Media, Culture, E Society, 31, 807-827.

Donaldson, L. (1996). The normal science of structural contingency theory. In S. Clegg \& C. Hardy (Eds.), Studying organization: Theory and method (pp. 51-70). London: Sage.

Eastman, S. T., \& Ferguson, D. (1997). Broadcast/cable programming: Strategies and practices (3rd ed.). Belmont, CA: Wadsworth.

Eikhof, D. R., \& Haunschild, A. (2007). For art's sake! Artistic and economic logics in creative production. Journal of Organizational Behavior, 28, 523-538.

Ellis, J. (2000). Scheduling: The last creative act in television? Media, Culture, \& Society, 22, 25-38.

Gallagher, M. (1982). Negotiation of control in media organizations and occupations. In M. Gurevitch, T. Bennett, J. Curran, \& J. Woollacott (Eds.), Culture, society and the media (pp. 151-173). London: Methuén.

Gunn, S. E. (2008). Redefining public service broadcasting: Multi-platform participation. Convergence, 14, 105-120.

Hazelkorn, E. (1995). Ireland: From nation building to economic priorities. In M. de Moragas Spà \& C. Garitaonanda (Eds.), Decentralization in the global era: Television in the regions, nationalities and small countries of the European Union (pp. 95-118). London: John Libbey.

Heckscher, C. (1994). Defining the post-bureaucratic type. In C. Heckscher \& A. Donnellon (Eds.), The post-bureaucratic organization: New perspectives on organizational change (pp. 14-62). Newbury Park, CA: Sage.

Hellman, H. (1999). From companions to competitors: The changing markets and television programming in Finland. Unpublished doctoral dissertation, University of Tampere, Finland.

Hesmondhalgh, D. (2007). The cultural industries (2nd ed.). London: Sage.

Hesmondhalgh, D., \& Baker, S. (2006, September). Creative work in the cultural industries. Symposium on Media and Cultural Industries conducted at the Museum des Sciences de L'Homme, Paris, France. 
Höpfl, H. (2006). Post-bureaucracy and Weber's "modern" bureaucrat. Journal of Organizational Change Management, 19, 8-21.

Hujanen, T. (2000). Programming and channel competition in European television. In J. Wieten, G. Murdock, \& P. Dahlgren (Eds.), Television across Europe: A comparative introduction (pp. 65-83). London: Sage.

Hujanen, T. (2002). The power of the schedule. Tampere, Finland: University of Tampere Press.

Hujanen, T. (2004). Public service strategy in digital television: From schedule to content. Journal of Media Practice, 4(3), 133-153.

Humphreys, P. (1996). Mass media and media policy in western Europe. Manchester, England: Manchester University Press.

Kärreman, D., \& Alvesson, M. (2004). Cages in tandem: Management control, social identity, and identification in a knowledge-intensive firm. Organization, 11, 149-175.

Kelly, M., \& Treutzschler, W. (1997). Ireland. In B. S. Ostergaard (Ed.), The media in western Europe (pp. 110-123). London: Sage.

Küng, L. (2008). Strategic management in the media: Theory to practice. London: Sage.

Logical and KPMG. (2002). RTÉ strategic framework report. Dublin, Ireland: RTÉ.

McSweeney, B. (2006). Are we living in a post-bureaucratic epoch? Journal of Organizational Change Management, 19, 22-37.

Meier, H. E. (2003). Beyond convergence: Understanding programming strategies of public broadcasters in competitive environments. European Journal of Communication, 18, 337-365.

Moe, H. (2008). Discussion forums, games and Second Life: Exploring the value of public broadcasters' marginal online activities. Convergence, 14, 261-276.

Murdock, G. (1993). Authorship and organisation. In M. Alvarado, E. Buscombe, \& R. Collins (Eds.), The screen education reader (pp. 123-143). New York: Columbia University Press.

Murray, A. M. (2011). Rationalising public service: Scheduling as a tool of management in RTÉ Television. Unpublished doctoral dissertation, Dublin Institute of Technology, Dublin, Ireland.

Napoli, P. (2001). The unpredictable audience: An exploratory analysis of forecasting error for new prime-time network television programs. Journal of Advertising, $30(2), 53-60$.

Nissen, C. (2011). Organisational cultures and structures in public media management - In search of a model for the digital era? Paper presented at The Danish Management Conference. Retrieved July 2012 from http://static.square space.com/static/508d6291e4b01df297a13497/t/50bb1aaae4b05ce48944e1ec/ 1354439338214/Cultures\%20and\%20structures\%20in\%20Media\%20Management \%20version\%202.0.pdf

Procter, S. (2005) Organizations and organized systems: From direct control to flexibility. In S. Ackroyd, R. Batt, P. Thompson \& P. Tolbert (Eds.) The Oxford handbook of work and organization (pp. 462-484). Oxford, UK: Oxford University Press.

Sennett, R. (2006). The culture of the new capitalism. New Haven, CT: Yale University Press. 
Shaw, H., Picard, R., \& Abbink Spaink, H. (2010). Irish broadcasting landscape: Economic and environmental review for the broadcasting authority of Ireland. Retrieved May 2011 from http://www.bai.ie/wordpress/wp-content/uploads/ 20110323_StratEconAnlysRpt_vFINAL_AC.pdf

Søndergaard, H. (2002, January). From programme-making to scheduling in Nordic Public Service Television - Or why programme production isn't the soul of public service. Paper presented at the RIPE@2002 conference, Helsinki and Tampere, Finland.

Tracey, M. (1998). The decline and fall of public broadcasting. New York: Oxford University Press.

Walton, E. (2005). The persistence of Weber: A meta-analysis of Weber's model of bureaucratic control. Organization Studies, 26, 569-600.

Weber, M. (1978). Economy and society: An outline of interpretative sociology (G. Roth \& C. Wittich, Trans. \& Eds.). Berkeley, CA: University of California Press.

Ytreberg, E. (2000). Scheduling in Nordic Public Service Television: General description of an ongoing research project. Nordicom Review, 1, 25-31.

Ytreberg, E. (2002). Continuity in environments: The evolution of basic practices and dilemmas in Nordic television scheduling. European Journal of Communication, 17, 283-304. 